\title{
Light Microscopy and Scanning Electron Microscopy of Colpocephalum nanum Piaget, 1890 (Phthiraptera: Amblycera: Colpocephalidae)
}

Colpocephalum nanum Piaget, 1890 (Phthiraptera: Amblycera: Colpocephalidae)' un Işık ve Taramalı Elektron Mikroskopisi

\section{Bilal Dik ${ }^{10}$, Ali Halajian² (D, Martin Turner ${ }^{3}$}

1Department of Parasitology, Selçuk University Faculty of Veterinary, Konya, Turkey 2Department of Biodiversity, University of Limpopo, Private Bag X1106, Sovenga, South Africa ${ }^{3}$ Electron Microscope Unit, University of Limpopo, Medunsa Campus, Pretoria, South Africa

Cite this article as: Dik B, Halajian A, Turner M. Light Microscopy and Scanning Electron Microscopy of Colpocephalum nanum Piaget, 1890 (Phthiraptera: Amblycera: Colpocephalidae). Turkiye Parazitol Derg 2018; 42(3): 207-12.

\section{ABSTRACT}

Objective: The aim of this study was to examine the morphological characteristics of Colpocephalum nanum (C. nanum) Piaget, 1890 using light microscopy (LM) and scanning electron microscopy (SEM).

Methods: For this purpose, the C. nanum specimens collected from long-legged buzzards, Buteo rufinus (B. rufinus) (Accipitriformes: Accipitridae), in Turkey were examined under LM and SM for morphological characteristics. The specimens were fixed and kept in $70 \%$ ethanol, cleared and mounted on the slides in Canada balsam. They were examined for morphological characteristics under LM. Some of the samples were put in a plate on absorbing paper and kept overnight, for ether to evaporate. These samples were mounted on aluminum stubs to study the ventral surface by placing them on their dorsal or ventral surface on double-sided adhesive tape. They were sputter-coated three times with gold, each time for approximately 7 minutes and later viewed using SEM (Zeiss SUPRA 55 VP FE-SEM and Zeiss EVO IS 10).

Results: Parts of the specimens were photographed, and the obtained data about morphological characteristic were evaluated in detail.

Conclusion: The LM and SEM photos of $C$. nanum were compared, and information about the important criteria for diagnosis and other morphological characteristics was obtained.

Keywords: Amblycera, lice, SEM, ectoparasite, Turkey

Received: 13.12.2017 Accepted: 02.04.2018

\section{Öz}

Amaç: Bu araştırma Colpocephalum nanum (C. nanum) Piaget, 1890'un morfolojik özelliklerinin ışık mikroskobunda ve taramalı elektron mikroskobunda (SEM) incelemek amacıyla yapılmıştır.

Yöntemler: Bu amaçla Türkiye'deki bir Kızıl Șahin'den (Buteo rufinus: B. rufinus) (Accipitriformes: Accipitridae) toplanan C. nanum örnekleri ışık mikroskobu ve taramalı elektron mikroskobunda morfolojik özellikleri yönünden incelenmiş ve bu konuda bilgi verilmiştir. Örneklerin bazıları \%70 alkolde saklanmış, \%10'luk Potasyum hidroksitte $(\mathrm{KOH})$ saydamlaştırımış, ve Kanada balsam ile lam üzerine yapıştıılmıştır. Preparatlar morfolojik özellikleri yönünden binoküler ışık mikroskobunda (Leica DM750) incelenmiştir. Bazı örnekler ise eterin uçması için gece boyunca bir levha üzerindeki emici bir kağıt üzerinde bekletildi ve aluminyum levhalara dorsal veya ventral yüzleri çalışılacak şekilde yerleştirildi. EMSCOPE SC500 veya CROSSINGTON 108 sputter coater'de, her seferinde yaklaşık olarak 7 dakika süreyle, üçer kez altınla kaplandı ve sonra Scanning Electron Microscope (SEM) (Zeiss SUPRA 55 VP FE-SEM ve Zeiss EVO IS 10) ile bazı yerlerin görüntüleri alındı.

Bulgular: Alınan görüntüler incelenerek morfolojik olarak değerlendirildi. ve morfolojik özellikleri hakkında ayrıntılı bilgiler elde edildi.

Sonuç: C.nanum'un ışık mikroskobu ve SEM'deki görüntüleri karşılaştırmalı olarak incelendi ve teşhis için önemli kriterler ve diğer morfolojik özellikleri hakkında bilgi verildi.

Anahtar Kelimeler: Amblycera, bit, SEM, Ektoparazit, Türkiye

Geliş Tarihi: 13.12.2017

Kabul Tarihi: 02.04.2018

This study was presented as oral presentation in 18 $8^{\text {th }}$ National Parasitology Congress in Denizli in Turkey, 2003 (SB03-10, page 137). Bu çalışma 2003 yılında Denizli'de düzenlenen 18. Ulusal Parazitoloji Kongresi'nde sözlü sunu olarak sunulmuştur (SB03-10, sayfa 137).

Address for Correspondence / Yazışma Adresi: Bilal Dik E.mail: bdik2005@yahoo.com DOI: $10.5152 /$ tpd.2018.5808

CCopyright 2018 Turkish Society for Parasitology - Available online at www.turkiyeparazitolderg.org

(C)Telif hakkı 2018 Türkiye Parazitoloji Derneği - Makale metnine www.turkiyeparazitolderg.org web sayfasından ulaşılabilir. 


\section{INTRODUCTION}

The genus Colpocephalum Nitzsch, 1818, as presently defined by most workers, is known to occur in birds from a number of different orders. The genus Colpocephalum, as found on the Accipitriformes, is characterized by combs of short spiniform setae restricted to the venter of femora III and abdominal sternite III, but the ventral sclerites bearing setae between the vulva and anus are absent in females. It was noticed that the species belonging to flavescens, impressum, osborni, turbinatum, zerafae, and chelictiniae groups have five long and three short setae on each side margin of the prothorax, and Colpocephalum nanum (C. nanum) Piaget, 1890 forms part of the osborni group (1). Pérez-Jiménez et al. (2) reported Colphocephalum meridionale (C. meridionale) as a new species from the common buzzard (Buteo buteo: $B$. buteo) in southern Spain. However, Price et al. (3) stated that $C$. meridionale was a new synonym of $C$. nanum.

The lice species found on Accipitriformes have not been studied sufficiently in Turkey. There are only a few studies on the chewing lice of Accipitriformes in Turkey (4-8). Dik (4) recorded Colpocephalum spp. from Buteo rufinus for the first time in Turkey. He stated that the male genitalia of Colpocephalum spp. resembles that of $C$. flavescens, $C$. turbinatum, and $C$. nanum, but the latero-posterior projections of the genital sclerites were not clearly visible due to the slides' poor condition, and it may belong to the flavescens, turbinatum, or osborni groups because of the penis barbed. Recently, C. nanum has been reported from Buteo rufinus ( $B$. rufinus) and $B$. buteo at different locations in Turkey (68). Nevertheless, there is not any comparative morphologic study of this lice species with scanning electron microscopy (SEM) and light microscopy (LM).

This study was conducted to examine morphological characteristics of $C$. nanum using LM and SEM.

\section{METHODS}

While examining the lice of the long-legged buzzard (B. rufinus) and common buzzard ( $B$. buteo) in Konya province, Turkey several specimens of $C$. nanum were obtained. The specimens were fixed and kept in $70 \%$ ethanol. For the morphological study in the lab, the lice were cleared in $10 \% \mathrm{KOH}$, washed in distilled water, dehydrated in the ascending concentrations of ethanol $(70 \%$, $80 \%, 90 \%$, and 99\%) for 24 hours in each step, and mounted on the slides in Canada balsam. The lice specimens were examined for morphological characteristics under a compound microscope (Leica DM750; Leica Microsystems, Wetzlar, Germany).

In addition, one female and one male specimen collected from a long-legged buzzard were checked morphologically under LM without clearing or using any chemicals. Then the specimens were dehydrated in the ascending ethanol series (80\%, 90\%, 95\%, $100 \%), 2$ hours in each step, and cleared by being placed in a 50/50 solution of $100 \%$ ethanol and LCS clearing solution (isopropanol, ether, chloroform, and acetone). They were placed in a $100 \%$ LCS for a day, and finally in pure ether, and were ready for the EM study.

Some of the samples were put in a plate on absorbing paper and kept overnight for ether to evaporate. These samples were mounted on aluminum stubs to study the ventral surface by plac- ing them on their dorsal surface on double-sided adhesive tape. They were sputter-coated three times with gold, in a sputter coater (EMSCOPE SC500; Quorum Technologies Ltd, East Sussex, United Kingdom), for 7 minutes each time, and later viewed using SEM (Zeiss SUPRA 55 VP FE-SEM; Carl-Zeiss Jena; Jena, Germany) in University of Limpopo, South Africa. The other samples (3 males, 3 females) were mounted on aluminum stubs to study the dorsal surface by placing them on their ventral surface on double-sided adhesive tape. They were sputter-coated with a gold auto sputter coater (Cressington 108; Cressington Scientific Instruments, Watford, England) and viewed using SEM (Zeiss Evo IS 10; Carl-Zeiss Jena; Jena, Germany) in Selcuk University, Konya, Turkey.

All the morphologic characteristics found during the LM were verified with the SEM study. The morphological terminology follows Clay (9). The scientific names of the birds follow Clements et al. (10). All measurements are given in millimeters $(\mathrm{mm})$.

\section{RESULTS}

In LM, the female is relatively small (Figure 1a). The head is triangular and strongly sclerotized, approximately one and a half times as wide as long. The anterior margin is smooth or slightly concave. The antenna has four segments. The maxillary palpi have four segments. Preocular and occipital nodi are well developed. Two long setae are observed on each side of the temple. The thorax is rather short; it is shorter than the head. The prothorax is small, and it has five long and three short setae on each side marginally. The prosternal plate has four setae. The mesosternal plate has nine to ten setae. There are two ctenidia on each side of the abdominal segment III. In females, tergocentral setae of abdomen are tergum II, 9; III, 10; IV, 7; V, 10; VI, 8; VII, 6; VIII, 6. The anus is indented dorsally. The post-spiracular setae are very long except on segment IV. The head length is 0.37-0.41 mm; head width, 0.52-0.54 mm; head index, 1.31-1.40; thorax length, $0.25-0.35 \mathrm{~mm}$; thorax width, 0.45-0.47 mm; abdomen length, 1.10-1.22 mm; abdomen width, 0.65-0.67 mm; and total length, 1.76-1.94 mm.

In SEM, the body is small and narrow (Figures $1 \mathrm{~b}, \mathrm{c}$ ). The head is triangular, narrowed in front and much extended in the temporal region (Figure 1d). The anterior margin of the head is flat. Mouthparts could not be seen clearly due to poor clearing of the sample. The antenna has four segments. The first (scape) and third segments are very small, and the terminal segment is the largest and ridged. The third segment is wineglass shaped (Figure 1e). There are more than ten sensilla basiconica of different sizes on the tip of the last segment of the antenna; two of them are stout, striated longitudinally as cactus-shaped as others, only thicker. There are two sensilla coeloconica on the last antennal segment; one of them is on the tip of the apex, and the other is lateral (Figure 1f). The maxillary palpus has four segments; the second and third segments are equal, and the last is the longest (Figure 1e). The gular plate is relatively prominent and has four setae on each side. The prothorax is small and has five long postero-marginal setae on each side (Figure 1d). There are three ctenidia on the ventral side of the third legs (Figure $1 \mathrm{~b}$ ). The legs are short and have two tarsal claws. The tarsal claws are strong and concave, and tapered in the tip. There is a unguitractor ventral side of the tarsal claws (Figure $1 \mathrm{~h}$ ). The abdomen is oval and relatively nar- 

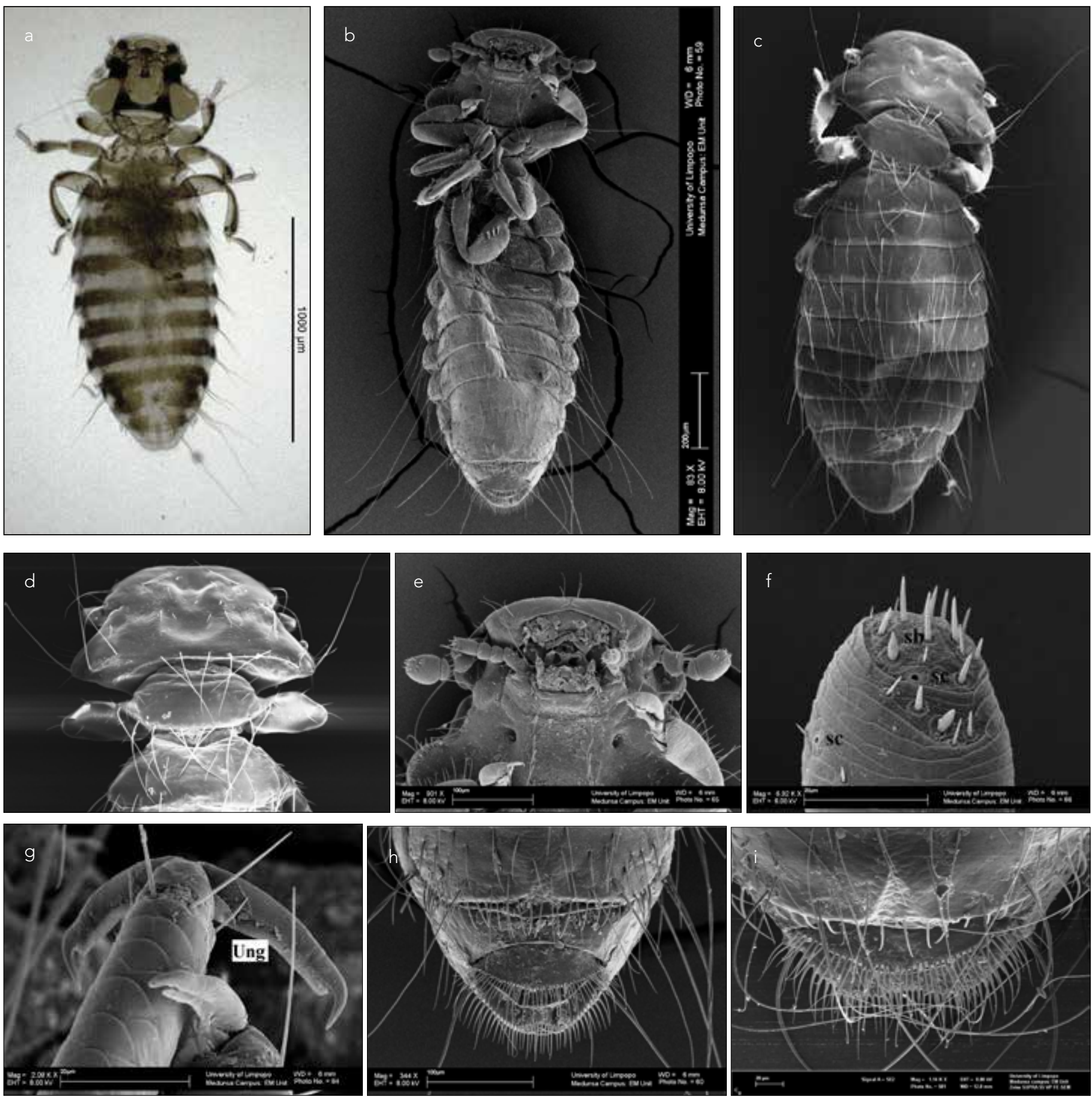

Figure 1. a-i. Photos of Colpocephalum nanum. (a) Female, LM. (b) Female, ventral, SEM. (c) Female, dorsal, SEM. (d) Female head, dorsal, SEM. (e) Female head, ventral, SEM. (f) Female antenna, sb: Sensilla besiconica, sc: Sensilla coeloconica, SEM. (g) Female, tarsal claws, unguitractor, SEM. (h) Female, abdominal end, ventral, SEM. (i) Female, abdominal end, ventral and dorsal fringes, SEM, original

row. Tergite IX has a long seta on each side. The posterior end of the abdomen is slightly indented in terminal. There are 14 short setae on the anterior margin of the vulvae opening. There are 37 on the inner side and 38-40 on the outer side of the anus, which are relatively minute setae in a regular row (Figures $1 \mathrm{~h}, \mathrm{i}, 2 \mathrm{2a}$ ).

The male resembles the female but is shorter than the female in LM (Figures $2 b, c)$. The occipital setae are very long. Prothorax has five long and three short setae on each side marginally. The prosternal plate has three setae, and the metasternal plate nine to thirteen setae. Post-spiracular setae are very long except on the IV abdominal segment. Tergum IX is without the anterior setae. The genital sclerite has no postero-lateral projections. The penis is barbed. The head length is $0.36-0.41 \mathrm{~mm}$; head width, 0.45-0.50 mm; cephalic index, 1.15-1.38; thorax length, $0.32 \mathrm{~mm}$; thorax width, 0.40-0.41 mm; abdomen length, 0.91-0.97 $\mathrm{mm}$; abdomen width, 0.55-0.58 mm; total length, 1.58-1.66 mm. 

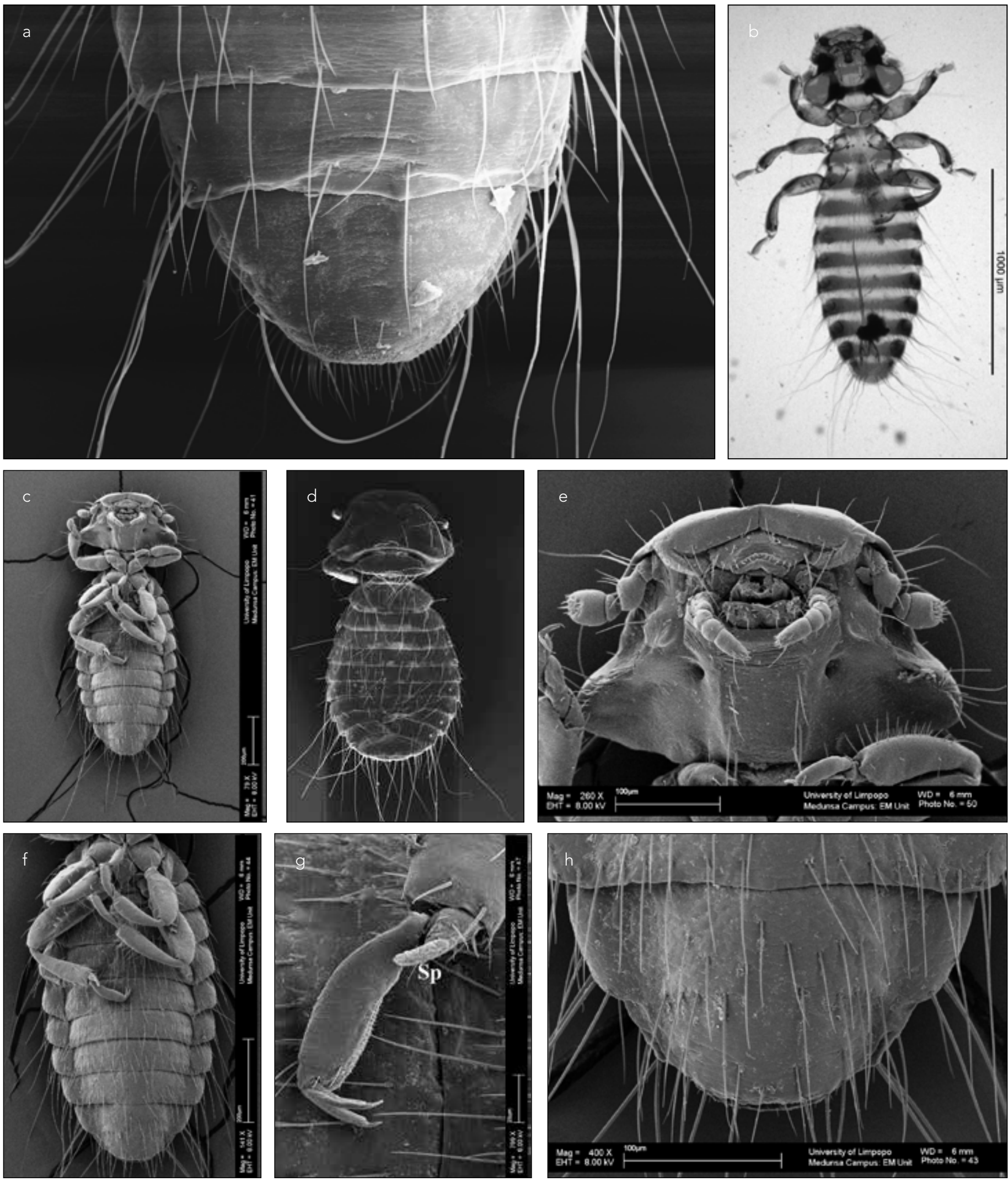

Figure 2. a-h. Photos of Colpocephalum nanum. (a) Female, abdominal end, ventral, SEM. (b) Male, ventral, light microscope. (c) Male, ventral, SEM. (d) Male, dorsal, SEM. (e) Male head, ventral, SEM. (f) Male thorax and abdomen, ventral, SEM. (g) Male tarsal claws, sp: spinous process, SEM. (h) Male abdominal end, ventral, SEM, original 
In SEM, the male is similar to the female but is shorter (Figures $2 c, d)$. The shape of the head and the morphologic characteristics of the head are similar to that of the female (Figure 2e). Tibia III has a spinous process near the apex and two claws (Figures $2 \mathrm{f}, \mathrm{g})$. The abdomen is relatively short and narrow. There are two setae row on the sternites. Post-spiracular seta IV is shorter than the others. VIII and IX sternites are fused. The anus is located in terminal (Figure $2 \mathrm{~h}$ ).

\section{DISCUSSION}

The species of Colpocephalum found on Falconiformes were discussed by Price and Beer (1). These authors recognized and discussed 25 species of Colpocephalum found in hawks in their paper. They stated that $C$. nanum is found on different species of buzzards, hawks, and falcons. However, they did not report C. nanum in long-legged buzzard (B. rufinus). Price et al. (3) reported the hosts of this species as Accipiter (A.) cooperii, A. gentilis, A. melanoleucus, A. nisus, A. striatus, Buteo (B.) buteo, B. jamaicensis, B. lagopus, B. lineatus, Circaetus cinereus, and Larus canus. According to the authors $(1,11,12)$, this species was described in Larus canus by Piaget, but they also stated that this host information is incorrect. Recently, $C$. nanum was retrieved from longlegged buzzards and buzzards (B. buteo) in Turkey $(4,6-8)$.

Séguy (13) recorded that the length of $C$. nanum is $1.25 \mathrm{~mm}$, and the host of this species is Larus canus. According to Martin-Mateo (11) the length of $C$. nanum ranges between 1.26 and 1.44 $\mathrm{mm}$ for males and 1.52 and $1.70 \mathrm{~mm}$ for females. In this study, the lengths of $C$. nanum specimens varied between 1.58 and 1.66 $\mathrm{mm}$ in males and 1.76 and $1.94 \mathrm{~mm}$ in females.

There are some papers explaining relevant morphological characteristics of some Ischnoceran, Amblyceran, or Anopluran lice species with LM and SEM (14-25). Although Clay (14) published a photo of the femoral comb of Colpocephalum spp., however, we could not find any description of $C$. nanum observed under SEM in literature. Clay $(14,15)$ gave very valuable information about the morphological characteristics of genus Menoponidae and the suborder Amblycera by using SEM in her papers. Clay (14) stated that the antenna has the scape, pedicel, and a flagellum with three segments; the last two in Amblycera are frequently fused to form a single segment. In addition to the sensory setae, there are sensory organs on the last two segments of the flagellum or on the terminal segment only. The Menoponidae have a sensillum coeloconicum on each of the last two segments in the five-segmented antenna. The Boophidae and the Ricinidae also have this arrangement of the sensilla; the Laemobothriidae with four segments differ in having three sensilla on the terminal segment. She also stated that there are a number of setae, sometimes cone shaped, and two sensilla, which seem to be sensilla coeloconicae on the terminal segment of the antenna (15). In this study, more than ten sensilla basiconica and two sensilla coeloconica were detected, one of them located on the tip, and the other on the lateral side of the last antennal segment. Clay (14) reported that many species have many outer dorsal setae on tibia I and only a few on tibiae II and III, while in others (Colpocepahlum complex), there were numerous marginal and submarginal setae in this position. In this study, many marginal and submarginal setae on tibia I of C. nanum were detected as stated by Clay (14). Cope (26) stated that the tibiae of all the legs bear a spinous process near the apex in the Piagetiella (Tetropthalmus) spp. Some authors $(14,27)$ gave descriptions of tarsal claws of some species from the Menoponidae family. It has been stated that the unguitractor in the adult is in the form of two plates, and it is attached to the tendon-like apodeme of the retractor muscle of the claws. In this study, a spinous process was seen near the apex of tibia III, while the others were not examined in this position, and the unguitractor was detected on the ventral sides of the tarsal claws. The authors $(1,4)$ reported that the anus indented dorsally, and the post-spiracular setae were very long in all abdominal segments, except segment IV. However, the number of setae on the dorsal and ventral fringes has not been stated. In this study, it was seen that the post-spiracular setae are very long, except in segment IV. In addition, there are 37 and 38 setae on the ventral and dorsal fringes, respectively.

\section{CONCLUSION}

SEM is more suitable for examining some morphological characteristics that cannot be seen in detail with LM. SEM can be used in differential diagnosis, if morphologic characteristics of the lice species are very similar, and scientific works for examining certain details of morphologic characteristics of the lice species. On the other hand, male genitalia, which are an important morphologic characteristic in the identification of the lice species, cannot be examined by SEM. In addition, SEM is an expensive method for the identification of ectoparasites, and it cannot be found in every lab. For these reasons, it is not used routinely.

Ethics Committee Approval: No need Ethics committee approval. Because the materials of the study had become, that previously collected specimens of dead Colpocephalum nanum in our stock.

Peer-review: Externally peer-reviewed.

Author Contributions: Concept - B.D., A.H.; Design - B.D., A.H., M.T.; Supervision - B.D., A.H., M.T.; Resources - B.D.; Materials - B.D.; Data Collection and/or Processing - B.D., A.H., M.T.; Analysis and/or Interpretation - B.D., A.H., M.T.; Literature Search - B.D., A.H.; Writing Manuscript - B.D., A.H., M.T.; Critical Review - B.D., A.H., M.T.

Conflict of Interest: Authors have no conflicts of interest to declare.

Financial Disclosure: The authors declared that this study has received no financial support.

Etik Komite Onayı: Bu çalışma için etik komite onayına gerek yoktur. Çünkü araştırma materyali daha önceki araştırmalarda toplanmış ölü Colpocephalum nanum örneklerinden oluşmuştur.

Hakem Değerlendirmesi: Dış bağımsız.

Yazar Katkıları: Fikir - B.D., A.H.; Tasarım - B.D., A.H., M.T.; Denetleme B.D., A.H., M.T.; Kaynaklar - B.D.; Malzemeler - B.D.; Veri Toplanması ve/ veya İşlemesi - B.D., A.H., M.T.; Analiz ve/veya Yorum - B.D., A.H., M.T.; Literatür Taraması - B.D., A.H.; Yazıyı Yazan - B.D., A.H., M.T.; Eleştirel Inceleme - B.D., A.H., M.T.

Çıkar Çatışması: Yazarlar çıkar çatışması bildirmemişlerdir.

Finansal Destek: Yazarlar bu çalışma için finansal destek almadıklarını beyan etmişlerdir. 


\section{REFERENCES}

1. Price RD, Beer JR. Species of Colpocephalum (Mallophaga: Menoponidae) Parasitic upon the Falconiformes. Can Entomol 1963; 95 : 731-63. [CrossRef]

2. Pérez-Jiménez JM, Soler-Cruz MD, Benitez-Rodriguez R, Diaz-Lopez M, Ruiz-Martinez I. Mallophaga of Buteo b. buteo in southern Spain. Angew Parasitol 1988; 29: 189-200.

3. Price RD, Palma RL, Hellenthal RA. New synonymies of chewing lice (Phthiraptera: Amblycera, Ischnocera) described from the Falconiformes (Aves). Eur J Entomol 1997; 94: 537-45.

4. Dik B. Mallophaga Species on Long-legged Buzzards (Buteo rufinus). New Records from Turkey. Turkiye Parazitol Derg 2006; 30: 226-30.

5. Gülanber A, Kaya Ü, Vaassen EWAM, Yavuz E. Chewing-lice on longlegged Buzzard. Indian Vet J 2006; 83: 1238-9.

5. Dik B, Aydenizöz-Özkayhan M. Mallophaga species on Long-legged Buzzards (Buteo rufinus) in Turkey. Turkiye Parazitol Derg 2007; 31: 298-301.

6. Dik B. Türkiye'de evcil ve yabani kanatlılarda görülen bit türleri. Turkiye Parazitoloji Derg 2010; 34: 55-60.

7. Inci A, Dik B, Kibar M, Yıldırım A, Düzlü Ö. Chewing Lice (Phthiraptera) Species on Wild Birds in Cappadocia Region, Turkey. Turkiye Parazitol Derg 2010; 34: 174-8. [CrossRef]

8. Clay T. An introduction to a classification of the avian Ischnocera (Mallophaga): Part I. Trans R Entom Soc Lond 1951; 102: 171-95. [CrossRef]

9. Clements JF, Schulenberg TS, Iliff MJ, Sullivan BL, Wood CL, Roberson D 2012. The eBird/Clements checklist of birds of the world: Version 6.7. Available from http://www.birds.cornell.edu/clementschecklist/downloadable-clements-checklist.

10. Martin Mateo MP. Mallophaga, Amblycera. Fauna Ibérica, 20. (ed. by M.A.Ramos et al). Museo Nacional de Ciencias Naturales (CSIC), Madrid, 2002.

11. Séguy E. Insectes Ectoparasites (Mallophages, Anoploures, Siphonaptéres), 43. Faune de France. Paul Lechevalier et Fils, Paris, 1944

12. Price RD, Hellenthal RA, Palma RL, Johnson KP, Clayton DH. The Chewing Lice: World checklist and biological overview. Illinois Natural History Survey Special Publication, $24 x+501$ p, 2003.

13. Clay T. A key to the genera of the Menoponidae (Amblycera: Mallophaga: Insecta). Bull Brit Mus (Nat Hist) Entom 1969; 24: 1-26. [CrossRef]
14. Clay T. The Amblycera (Phthiraptera: Insecta). Bull Brit Mus (Nat Hist) Entom 1970; 25: 75-98. [CrossRef]

15. Bansal N, Khan V, Ahmad A, Gaurav A, Saxena AK. Contribution to the characteristics of Alcedoecus annulatus (Insecta: Phthiraptera; Ischnocera). Ann Entomol 2008; 26: 5-9.

16. Cicchino AC, Muňoz Cobeňas ME, Bulman GM, Diaz JC, Laos A. Identification of Microthoracius mazzai (Phthiraptera: Anoplura) as an economically important parasites of Alpacas. J Med Ent 1998; 35: 922-30. [CrossRef]

17. Khan V, Bansal N, Gaurav A, Ahmad A, Saxena AK. Contribution to the morphology of Degeeriella regalis. (Insecta: Phthiraptera; Ischnocera). J Ent Res 2011; 35: 93-6.

18. Sebei PJ, Mccirndle CME, Green ED, Turner ML. Use of scanning electron microscopy to confirm the identity of lice infesting communally grazed goat herds. Onderstepoort J Vet Res 2004; 71: 87-92. [CrossRef]

19. Turner ML. The micromorphology of the blesbuck louse Damalinia (Damalinia) crenelata as observed under the scanning electron microscope. Koedoe 2003; 46: 65-71. [CrossRef]

20. Turner ML, Baker C, Marais R. Scanning electron microscopical investigation of the waterbuck louse Bovicola (syn. Damalinia) hilli found at the Rietvlei Nature Reserve near Pretoria. Koedoe 2002; 45: 59-63. [CrossRef]

21. Ubelaker JE, Payne E, Allison VF, Moore DV. Scanning Electron Microscopy of the human pubic louse Phthirius pubis (Linnaeus, 1758). J Parasitol 1973; 59: 913-9. [CrossRef]

22. Zlotorzycka J, Modrzejewska M. Cechy morfologiczne ze szcsególnym uwzglednieniem ultrastruktur powierzchniowych u Docophoroides brevis (Docophoroididae, Mallophaga). Wiad Parazytol 1992; 38: 43-50.

23. Zlotorzycka J, Modrzejewska M, Saxena AK. Heterodoxus spiniger (Boophidae, Mallophaga) from Canis familiaris from India in the light and scanning electron microscope. Wiad Parazytol 1995; 41 : 455-62.

24. Dik B, Halajian A, Turner M. The morphology of Craspedorrhynchus platystomus (Burmeister, 1838), a louse commonly found on the long-legged buzzard Buteo rufinus (Phthiraptera: Ischnocera: Philopteridae). Turk J Zool 2013; 37: 739-45. [CrossRef]

25. Cope OB. The morphology of a species of the genus Tetrophthalmus (Mallophaga: Menoponidae). Microentomol 1941; 6: 71-92.

26. Kéler SV. Über den feineren bau der tarsen bei Pseudomenopon rowanae Kéler. Beitr zur Entomol 952: 2: 573-81. 